\title{
Chimariko Grammar
}


This page intentionally left blank 


\section{Chimariko Grammar Areal and Typological Perspective}

Carmen Jany

University of California Press Berkeley $\bullet$ Los Angeles $•$ London 
University of California Press, one of the most distinguished university presses in the United States, enriches lives around the world by advancing scholarship in the humanities, social sciences, and natural sciences. Its activities are supported by the UC Press Foundation and by philanthropic contributions from individuals and institutions. For more information, visit www.ucpress.edu.

University of California Publications in Linguistics, Volume 142

Editorial Board: Judith Aissen, Andrew Garrett, Larry M. Hyman, Marianne Mithun, Pamela Munro, Maria Polinsky

University of California Press

Berkeley and Los Angeles, California

University of California Press, Ltd.

London, England

(C) 2009 by The Regents of the University of California

Printed in the United States of America

Cataloging-in-Publication data for this title is on file with the Library of Congress.

ISBN 978-0-520-09875-6 (pbk. : alk. paper)

The paper used in this publication meets the minimum requirements of ANSI/NISO Z39.48-1992 (R 1997) (Permanence of Paper). 
To my parents 
This page intentionally left blank 